\title{
PENGARUH MODEL PEMBELAJARAN KOOPERATIF TIPE STUDENT TEAMS ACHIEVEMENT DIVISION TERHADAP HASIL BELAJAR TEKNIK DASAR SEPAK SILA DALAM PERMAINAN SEPAK TAKRAW
}

\author{
Ketut Ria Darmiyanti ${ }^{1}$, I Ketut Budaya Astra ${ }^{2}$, I Made Satyawan ${ }^{3}$ \\ 1,2,3 Program Studi Pendidikan Jasmani Kesehatan dan Rekreasi, Jurusan Pendidikan \\ Olahraga, Fakultas Olahraga dan Kesehatan \\ Universitas Pendidikan Ganesha \\ Singaraja, Indonesia
}

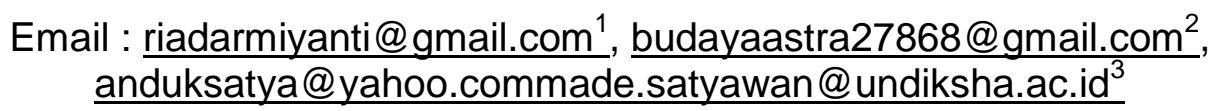

\begin{abstract}
ABSTRAK
Penelitian ini bertujuan mengetahui pengaruh model pembelajaran kooperatif tipe Student Teams Achievement Division (STAD) terhadap hasil belajar teknik dasar sepak sila dalam permainan sepak takraw. Penelitian ini merupakan penelitian eksperimen sungguhan (true experimental) dengan rancangan the randomized posttest control group the same subject design. Populasi yang digunakan adalah seluruh peserta didik kelas IX SMP Negeri 4 Kubutambahan tahun pelajaran 2019/2020, pengundian kelompok eksperimen (STAD) dan kelompok kontrol dilakukan dengan simple random sampling berdasarkan kelas. Sampel penelitian ini berjumlah 62 orang yang terdistribusi ke dalam dua kelas yaitu kelas IX A sebagai kelompok eksperimen dan kelas IX D sebagai kelompok kontrol. Data hasil belajar dikumpulkan melalui tes objektif, observasi dan unjuk kerja. Analisis data menggunakan Uji-t dengan angka signifikansi yang diperoleh adalah $p=0.012$ $<0,05$, yang menunjukkan bahwa penerapan model pembelajaran kooperatif tipe STAD berpengaruh signifikan terhadap hasil belajar teknik dasar sepak sila dalam permainan sepak takraw.
\end{abstract}

Kata kunci: Hasil Belajar, sepak takraw, STAD

\begin{abstract}
This study aimed to determine the effect of the Student Teams Achievement Division (STAD) cooperative learning model toward the learning outcomes of the basic techniques of sepak sila in sepak takraw game. This research was a real experimental study (true experimental) with the randomized posttest control group design the same subject design. The population who was used were all students of grade IX SMP Negeri 4 Kubutambahan to the 2019/2020 year, the drawing of the experimental group (STAD) and the control group were carried out by simple random sampling based on class. The sample of this study amounted to 62 people who were distributed into two classes, namely class IX A as an experimental group and class IX D as a control group. Learning outcomes data were collected through objective tests, observations and performance. Data analysis used t-test with the significance
\end{abstract}


value obtained was $p=0.012<0.05$, which showed that the application of the STAD type cooperative learning model had a significant effect on the learning outcomes of the basic techniques of tepak sila in the sepak takraw game.

Keywords: Learning Outcomes, sepak takraw, STAD.

\section{PENDAHULUAN}

Pendidikan merupakan kegiatan yang kompleks, dan meliputi berbagai komponen yang berkaitan erat satu sama lain. Oleh sebab itu, apabila pendidikan ingin dilaksanakan secara terencana dan teratur, maka berbagai faktor yang terlibat dalam pendidikan harus dipahami terlebih dahulu. Berbagai komponen dalam sistem pendidikan, baik secara mikro maupun dalam kajian makro perlu dikenali secara mendalam sehingga komponenkomponen tersebut dapat difungsikan dan dikembangkan guna mengoptimalkan garapan pendidikan tersebut ke arah pencapaian tujuan pendidikan yang ditetapkan (Dinn Wahyudi dkk, 2006) (Sutrisno, 2016).

Pendidikan dan pengajaran adalah suatu proses yang sadar tujuan. Tujuan dapat diartikan sebagai suatu usaha untuk memberikan rumusan hasil yang diharapkan siswa setelah melaksanakan pengalaman belajar (Sadirman, 2004). Tercapai tidaknya tujuan pengajaran salah satunya adalah terlihat dari prestasi belajar yang diraih siswa. Dengan prestasi yang tinggi, para siswa mempunyai indikasi berpengetahuan yang baik (Hamdu, 2011).

Pendidikan jasmani merupakan bagian yang tidak terpisahkan dari pendidikan nasional yang bertujuan untuk pengembangkan kemampuan peserta didik melalui aktivitas jasmani (Utama Bandi, 2011). Sehingga pendidikan jasmani harus diajarkan kepada setiap peserta didik pada semua jenjang pendidikan. Perencanaan pendidikan jasmani dilakukan secara seksama untuk memenuhi perkembangan, pertumbuhan, dan kebutuhan perilaku setiap anak.
Maka pendidikan jasmani bukan hanya ditujukan untuk mengembangkan kemampuan psikomotorik, akan tetapi juga mengembangkan kemampuan kognitif dan afektif peserta didik (Paramitha, 2018).

Peningkatan hasil pembelajaran dalam proses pembelajaran Pendidikan Jasmani Olahraga dan Kesehatan (PJOK) ditentukan antara lain oleh lembaga pendidikan, guru, peserta didik serta kurikulum. Selain itu model pembelajaran juga diperlukan untuk meningkatkan proses belajar peserta didik secara efektif. Tujuan dari penggunaan model pembelajaran adalah agar proses pembelajaran semakin bervariasi dan tidak membosankan, agar kegiatan belajar peserta didik semakin aktif, kreatif, dan inovatif karena mereka terlibat langsung dalam kegiatan pembelajaran.

Salah satu masalah yang dihadapi di dalam pembelajaran PJOK secara umum yaitu masih lemahnya proses pembelajaran. Dalam proses pembelajaran, peserta didik kurang berpartisipasi aktif karena lebih banyak mendapatkan model pembelajaran langsung. "Model pembelajaran langsung dengan metode ceramah memiliki kelemahan seperti siswa akan lebih bosan dan merasa mengantuk, karena dalam metode ini, hanya guru yang aktif dalam proses belajar mengajar, sedangkan para peserta didik hanya duduk diam mendengarkan penjelasan yang telah diberikan oleh guru" (Majid, 2009:138).

Berdasarkan hasil observasi awal yang dilakukan pada hari jumat 24 Oktober 2019 di SMP Negeri 4 Kubutambahan pada peserta didik kelas 
IX A berjumlah 32 peserta didik, IX B berjumlah 32 peserta didik, IX C berjumlah 30 peserta didik, kelas IX D berjumlah 30 peserta didik dan IXE berjumlah 31 peserta didik dalam mata pelajaran PJOK dengan materi teknik dasar sepak sila pada permainan sepak takraw, dalam proses pembelajaran masih mengalami masalah. Dalam pembelajaran masih ada peserta didik yang bercanda dengan temannya tanpa memperhatikan guru yang sedang menerangkan dan mendemonstrasikan materi pembelajaran, selain itu peserta didik kurang antusias dalam mengikuti pelajaran dan hanya melakukan apa yang diterangkan gurunya tanpa mengeluarkan kretifitasnya dalam pembelajaran tersebut. Hal ini terjadi karena guru kurang tepat dalam memilih model pembelajaran sehingga proses pembelajaran menjadi kurang efektif baik dari segi waktu maupun pemanfaatan fasilitas.

Jika dilihat dari hasil belajar pada materi sepak sila pada permainan sepak takraw, didapat data bahwa hasil ulangan harian materi bola besar yaitu teknik dasar sepak sila dalam permainan sepak takraw kelas IX masih banyak peserta didik yang belum memenuhi Kriteria Ketuntasan Minimal (KKM). Dengan rentangan KKM yang berlaku di kelas IX SMP Negeri 4 Kubutambahan khususnya pada mata pelajaran PJOK yang harus dicapai peserta didik adalah 75. Pada aspek pengetahuan dari 156 orang jumlah total peserta didik, 56 orang (36\%) peserta didik memperoleh nilai diatas KKM, dan sisanya 100 Orang (64\%) peserta didik memperoleh nilai kurang dari KKM. Sedangkan pada aspek keterampilan peserta didik yang mendapatkan nilai diatas KKM yaitu 60 orang $(38 \%)$, dan 96 orang $(62 \%)$ peserta didik memperoleh nilai kurang dari KKM. Sehingga dapat disimpulkan bahwa pembelajaran PJOK khususnya materi sepak sila dalam permainan sepak takraw pada peserta didik dikatakan belum berhasil untuk memaksimalkan hasil belajar.

Rendahnya hasil belajar yang diperoleh peserta didik menunjukkan bahwa adanya proses pembelajaran yang kurang optimal yang diterapkan pada saat pembelajaran karena masih menggunakan model pembelajaran langsung. Melihat hal tersebut maka peran guru sebagai pendidik perlu mendapat perhatian khusus dalam mengimplementasikan model pembelajaran yang tepat, karena dengan implementasi model pembelajaran yang tepat akan dapat memacu semangat para peserta didik di dalam mengikuti pelajaran dan mendorong peserta didik untuk mengembangkan antara pengetahuan yang dimiliki dengan pengetahuan yang didapat dari sekolah, sehingga para peserta didik akan bersikap aktif dalam mengikuti proses pembelajaran khususnya pelajaran PJOK.

Berdasarkan sebagaimana yang telah dideskripsikan di atas, maka untuk mengatasi permasalahan yang terjadi pada peserta didik kelas IX SMP Negeri 4 Kubutambahan pada proses pembelajaran PJOK perlu dicarikan alternatif pemecahan masalah, yaitu dengan melakukan inovasi model pembelajaran yang inovatif untuk meningkatkan hasil belajar peserta didik. Salah satu model pembelajaran yang bisa disarankan sesuai permasalahan yang terjadi adalah model pembelajaran kooperatif tipe Student Teams Achievement Division (STAD) dalam pelajaran PJOK pada materi teknik dasar sepak sila dalam permainan sepak takraw. Model pembelajaran kooperatif dengan tipe STAD ini dipilih karena (1) model pembelajaran kooperatif dengan tipe STAD adalah model pembelajaran yang sederhana, (2) pada model ini peserta didik lebih banyak mempunyai kesempatan diskusi kelompok dan memiliki tanggung jawab peseorangan untuk mengetahui materi sebaik-baiknya, (3) model pembelajarean STAD dapat 
mengajak siswa belajar aktif dan kreatif serta berani mengeluarkan pendapat dalam diskusi kelompok.

Pembelajaran kooperatif tipe STAD merupakan salah satu tipe dari model pembelajaran kooperatif dengan menggunakan kelompok-kelompok kecil dengan jumblah anggota tiap kelompok 45 orang siswa secara heterogen (Trianto, 2009:68). Langkah-langkah dalam model pembelajaran kooperatif tipe STAD diawali dengan penyampaian tujuan pembelajaran dan memberikan motivasi kepada peserta didk untuk belajar, penyampaian materi, kegiatan kelompok, kuis, dan memberikan pengharaan kepada kelompok.

Pembelajaran kooperatif tipe STAD ini merupakan salah satu tipe dari model pembelajaran kooperatif dengan menggunakan kelompok-kelompok kecil dengan jumlah anggota 4-5 orang siswa secara heterogen. Diawali dengan penyampaian tujuan pembelajaran, penyampaian materi, kegiatan kelompok, kuis, dan penghargaan kelompok (Trianto,2007:52). Menurut Slavin (2005: 143) bahwa "STAD merupakan salah satu metode pembelajaran kooperatif yang paling sederhana, dan merupakan model yang paling baik untuk permulaan bagi para peneliti yang baru menggunakan pendekatan kooperatif".

Menurut Slavin (2005:143-144), ada beberapa ciri-ciri model pembelajaran kooperatif tipe STAD yaitu "(1) Belajar dalam kelompok kecil, (2) Memperhatikan skor awal, (3) Kuis, (4) Skor kemajuan individu, dan (5) Penghargaan Kelompok". (1) Belajar dalam kelompok kecil, siswa di tempatkan dalam kelompok-kelompok belajar beranggotakan 4-5 orang yang heterogen menurut tingkat kemampuan, jenis kelamin, ras/suku.Dengan adanya heterogenitas anggota kelompok diharapkan dapat memotivasi siswa untuk saling membantu antar siswa dalam menguasai materi pelajaran. (2) Memperhatikan skor awal, skor awal adalah skor kuis diperoleh peserta didik dalam pembelajaran sebelumnya. Skor awal ini sangat berguna untuk mengetahui perkembangan siswa secara individu. (3) Kuis dimaksudkan untuk mengetahui tingkat penguasaan pengetahuan secara individual.Dalam mengerjakan kuis, peserta didik bekerja sendiri tanpa memperoleh bantuan dari siapapun.Dengan demikian siswa sebagai individu bertanggung jawab untuk memahami pelajaran. (4) Skor kemajuan individu digunakan untuk mengetahui kemajuan siswa secara individu yang diperoleh dengan membandingkan skor awal (based score) dengan skor kuis (quiz score).Dalam pembelajaran kooperatif tipe STAD skor kemajuan ini sangat diperlukan untuk menentukan skor kelompok yang nantinya digunakan untuk menentukan predikat masing-masing kelompok. (5) Penghargaan kelompok, langkah pertama sebelum memberikan penghargaan kelompok adalah menghitung rata-rata skor kelompok.Untuk memperoleh rata-rata skor dilakukan dengan menjumlahkan skor kemajuan masing-masing anggota kelompok, kemudian jumlah tersebut dibagi dengan jumlah anggota kelompok yang mengikuti kuis pada saat itu.

Model pembelajaran kooperatif tipe STAD juga memiliki keunggulan dan kelemahan. Keunggulan model pembelajaran kooperatif tipe STAD adalah sebagai berikut: (a) siswa lebih mampu mendengarkan dan menghormati serta menerima orang lain, (b) siswa mampu mendefinisikan akan perasaan, dan juga perasaan orang lain, (c) siswa dapat menerima pengalaman dan dapat dimengerti orang lain (d) siswa mampu menyajikan dirinya untuk orang lain dengan membantu orang lain dan meyakinkan dirinya untuk saling memahami serta mengerti, $n$ dan (e) siswa mampu mengembangkan potensi individu yang berhasil guna dan berdaya guna, kreatif, bertanggung jawab, mampu 
mengaktualisasikan, dan mengoptimalkan dirinya terhadap perubahan yang terjadi.

Kelemahan model pembelajaran kooperatif tipe STAD adalah sebagai berikut: (a) tidak bisa digunakan untuk pembelajaran yang membutuhkan penjelasan objektif, (b) ada siswa yang paling menonjol, (c) Peneliti dituntut membantu persiapan mengajar yang mantap dan ditunjang penguasaan materi bahan ajar yang luas, (d) siswa terbiasa mengerjakan soal secara berkelompok, dan (e) adanya perbedaan-perbedaan pembelajaran dalam memberikan pelajaran.

Pemilihan model pembelajaran STAD ini juga dikuatkan oleh hasil penelitian-penelitian terdahulu, diantaranya dilakukan oleh Suarta (2017), bahwa pengaruh penerapan model pembelajaran kooperatif tipe STAD berpengaruh signifikan terhadap hasil belajar teknik dasar pasing sepak bola. Penelitian serupa juga dilakukan oleh Arimbawa dkk. (2017), bahwa penerapan model pembelajaran kooperatif tipe STAD berpengaruh sangat signifikan terhadap peningkatan hasil belajar passing (menggunakan kaki bagian dalam) sepak bola. Hasil yang sama juga ditemukan oleh Tama dkk. (2019) bahwa penerapan model pembelajaran kooperatif tipe STAD berperngaruh signifikan terhadap peningkatan hasil belajar teknik dasar passing (menggunakan kaki bagian dalam dan kaki bagian luar) sepak bola.

Berdasarkan latar belakang, maka perlu dilakukan penelitian mengenai pengaruh model pembelajaran kooperatif STAD terhadap hasil belajar teknik dasar sepak sila dalam permainan sepak takraw pada peserta didik kelas IX SMP negeri 4 kubutambahan, yang dirumuskan dalam permasalahan penelitian berikut.Bagaimana pengaruh model pembelajaran kooperatif tipe STAD terhadap hasil belajar teknik dasar sepak sila dalam permainan sepak takraw pada peserta didik kelas IX SMP Negeri 4 Kubutambahan tahun pelajaran
2019/2020. Tujuan yang ingin dicapai dalam penelitian ini adalah untuk mengetahui pengaruh model pembelajaran kooperatif tipe STAD terhadap hasil belajar teknik dasar sepak sila dalam permainan sepak takraw pada peserta didik kelas IX SMP Negeri 4 Kubutambahan tahun pelajaran 2019/2020.

Hasil penelitian ini diharapkan dapat memberikan manfaat baik secara teoretis maupun praktis. Secara teoritis penelitian ini diharapkan mampu memberikan kontribusi sumbangan empiris bagi ilmu pengetahuan dan dapat menjadi rujukan bagi peneliti lain khususnya terkait dengan penerapan model pembelajaran kooperatif STAD terhadap teknik dasar sepak sila dalam permainan sepak takraw. Secara praktis, penelitian ini dapat membantu peserta didik dalam meningkatkan proses dan hasil belajar teknik dasar sepak sila dalam permainan sepak takraw, serta dapat meningkatkan wawasan dan keterampilan guru dalam proses pembelajaran PJOK dengan menerapkan model pembelajaran kooperatif tipe STAD. Selain itu penelitian ini juga dapat membantu sekolah meningkatkan pemberdayaan gerakan dan kecakapan hidup para peserta didiknya sehingga diharapkan dapat bersaing dalam kompetensi antar sekolah maupun untuk kepentingan melanjutkan studi ke jenjang yang lebih tinggi.

\section{METODE PENELITIAN}

Penelitian ini merupakan penelitian eksperimen sungguhan (true experimental) dengan rancangan penelitian the randomized posttest control group the same subject design. Dalam penelitian ini yang akan menjadi subjek penelitian adalah seluruh siswa kelas IX SMP Negeri 4 Kubutambahan tahun pelajaran 2019/2020 yaitu terdiri dari 156 orang siswa dan dibagi menjadi 5 kelas. Kelas tersebut diantaranya IX A yang berjumlah 32 orang, IX B yang berjumlah 
32 orang, IX C yang berjumlah 30 orang, IX D berjumlah 30 orang, dan IX E yang berjumlah 31 orang.

Pengambilan sampel dalam penelitian ini dilakukan dengan cara random dan yang menjadi sampel penelitian adalah seluruh siswa kelas IX SMP Negeri 4 Kubutambahan tahun pelajaran 2019/2020 yang terdistribusi ke dalam 2 kelas yaitu: IXA berjumlah 32 orang dan IXD berjumlah 30 orang, sehingga keseluruhan jumlah sampel penelitian adalah 62 orang. Dua kelas yang ada akan diundi untuk menetapkan kelas yang menjadi kelas eksperimen dan kelas kontrol. Pengambilan data hasil belajar dilakukan dengan cara memeberikan tes. Analisis data dilakukan dangan menggunakan Uji-t. Sebelum dilakukan Uji-t terlebih dahulu data diuji normalitas dan homogenitas.

\section{HASIL DAN PEMBAHASAN}

\section{Hasil Penelitian}

Penelitian ini dilakukan di SMP Negeri 4 Kubutambahan, penelitian ini dilakukan pada dua kelompok, yaitu kelompok eksperimen dan kelompok kontrol. Dalam penelitian ini kelompok eksperimen diberikan perlakuan berupa model pembelajaran kooperatif tipe STAD pada kelas IX A dan pada kelompok kontrol diberikan perlakuan berupa model pembelajaran konvensional (ceramah) pada kelas IX D. Hasil belajar teknik dasar sepak sila dalam permainan sepak takraw kelompok eksperimen yang berjumlah 32 orang diperoleh rata-rata nilai posttest sebesar 83,38 sedangkan kelompok kontrol yang berjumlah 30 orang rata-rata nilai posttest sebesar 80,70 .

Sebelum uji hipotesis dilakukan, terlebih dahulu dilakukan pengujian prasyarat terhadap sebaran data yang meliputi uji normalitas sebaran data dan uji homogenitas varians. Berdasarkan analisis yang telah dilakukan dengan menggunakan SPSS 16.00 for Windows didapatkan hasil bahwa untuk semua variabel signifikansi pada uji KolmogorovSmirnov yaitu pada kelompok experimen signifikansinya 0.200 dan pada kelompok kontrol signifikasinya 0.200 lebih besar dari 0,05. Dengan demikian maka semua sebaran data berdistribusi normal. Uji homogenitas varians antar kelompok dilakukan dengan Levene's Test Of Equality Error Variance. Hasil uji Levene's menunjukkan bahwa untuk hasil belajar teknik dasar sepak sila dalam permainan sepak takraw adalah 0,969 dengan taraf signifikansi 0,329 , dengan nilai sig untuk Uji Levine adalah 0,329 dimana lebih besar dari 0,05 sehingga tidak terdapat perbedaan varians kedua kelompok, oleh karena itu dapat disimpulkan bahwa variansi pada setiap kelompok adalah sama (homogen).

Pengujian hipotesis menggunakan uji t dengan bantuan SPSS 16.00 for Windows dengan menggunakan independent samples test. Berdasarkan hasi uji $\mathrm{t}$ diperoleh nilai signifikansin sebesar 0,012 maka $p<0,05$. Hasil ini dijadikan dasar dalam mengambil keputusan. Adapun keputusan yang diambil adalah tolak Ho dan terima $\mathrm{Ha}$. Hasil ini menyatakan bahwa terdapat perbedaan hasil belajar teknik dasar sepak sila dalam permainan sepak takraw antara peserta didik yang dibelajarkan menggunakan model pembelajaran kooperatif tipe STAD dengan peserta didik yang dibelajarkan menggunakan model pembelajaran konvensional. Berdasarkan angka rata-rata terlihat bahwa rata-rata peningkatan hasil belajar pada kelompok eksperimen lebih besar daripada kelompok kontrol. Dapat disimpulkan bahwa hasil belajar pada peserta didik yang dibelajarkan menggunakan model pembelajaran kooperatif tipe STAD lebih tinggi dari pada peserta didik yang dibelajarkan menggunakan model pembelajaran konvensional. 


\section{Pembahasan Hasil Penelitian}

Kurangnya kerjasama antara guru dan peserta didik satu dengan peserta didik yang lainnya yang menyebabkan proses pembelajaran tidak berjalan optimal dan maksimal. Model pembelajaran yang digunakan bersifat monoton serta kurang memperhatikan kemampuan individu peserta didik, padahal kemampuan individu setiap peserta didik belum tentu sama. Sehingga memerlukan inovasi pembelajran yang sesuai, agar hasil pembelajaran penjasorkes dapat berjalan sesuai dengan tujuan.

Berdasarkan hasil analisis data diperoleh bahwa terdapat perbedaan hasil belajar teknik dasar sepak sila dalam permainan sepak takraw antara peserta didik yang dibelajarkan dengan model pembelajaran kooperatif tipe STAD dengan peserta didik yang dibelajarkan dengan model pembelajaran konvensional, ini berarti model pembelajaran kooperatif tipe STAD berpengaruh terhadap hasil belajar teknik dasar sepak sila dalam permainan sepak takraw peserta didik. Lebih baiknya hasil penelitian pada kelompok eksperimen disebabkan oleh kegiatan pembelajaran yang menuntut peserta didik untuk lebih aktif dan dapat membuat kondisi kelas lebih aktif sehingga hasil belajar PJOK peserta didik meningkat.

Hasi penelitian ini sejalan dengan penelitian yang dilakukan oleh Suarta (2017) pengaruh penerapan model pembelajaran kooperatif tipe STAD berpengaruh terhadap hasil belajar teknik dasar passing sepak bola dengan angka signifikan yang diperoleh melalui uji $t$ adalah $0,000<0.05$. Sejalan juga dengan hasil penelitian yang dilakukan oleh Arimbawa dkk (2017), menyimpulkan bahwa penerapan model pembelajaran kooperatif tipe STAD berpengaruh sangat signifikan terhadap peningkatan hasil belajar passing (menggunakan kaki bagian dalam) sepak bola. Selain ituhasilpenelitian yang sama juga
diperolehTama dkk. (2019) bahwa penerapan model pembelajaran kooperatif tipe STAD berperngaruh signifikan terhadap peningkatan hasil belajar teknik dasar passing (menggunakan kaki bagian dalam dan kaki bagian luar) sepak bola.Awan, (2017), juga menemukan bahwa Pengaruh Model Pembelajaran Kooperatif Tipe STAD berpengaruh Terhadap Hasil Belajar Teknik Dasar Passing Control Sepak Bola Angka signifikansi yang diperoleh melalui Uji t adalah sig $<0.05$.

Perbedaan hasil belajar antara kelompok kontrol dan eksperimen secara kuantitatif dapat dianalisis melalui hasil post-test hasil belajar PJOK peserta didik. Nilai peserta didik pada kelompok eksperimen yaitu kelompok yang diberikan perlakuan dengan model pembelajaran kooperatif STAD cenderung lebih tinggi dibandingkan dengan nilai peserta didik pada kelompok kontrol. Hal tersebut disebabkan karena sebagian besar peserta didik pada kelompok eksperimen menunjukan antusiasme yang tinggi pada saat proses pembelajaran berlangsung.

Pada pertemuan awal, beberapa peserta didik pada kelompok eksperimen sudah menunjukan antusiasme mereka. Ketika peserta didik yang kurang aktif berkelompok dengan peserta didik yang aktif. Mereka yang kurang aktif saat diawal pembelajaran mulai mau untuk mempraktekan setiap gerakan teknik dasar sepak sila. Tentu saja semua itu dengan bantuan dan dukungan dari teman sekelompoknya. Dukungan yang diberikan dari teman sekelompoknya dapat berdampak pada peserta didik seperti lebih percaya diri dan memberanikan diri mencoba untuk tampil di depan. Saat kondisi seperti ini, sangat terlihat betapa berpengaruhnya model pembelajaran kooperatif khususnya model pembelajaran kooperatif tipe STAD untuk membangun keaktifan peserta didik sehingga dapat meningkatkan hasil belajar mereka. 
Pada tahap awal pembelajaran dengan model pembelajaran kooperatif tipe STAD, guru memberikan stimulus berupa uraian singkat mengenai materi yang akan dipelajari beserta beberapa contoh, kemudian dilanjutkan dengan menerapkan model pembelajaran kooperatif tipe STAD. Pada tahap ini peserta didik dipersilahkan membentuk kelompok. Peserta didik dengan anggota kelompoknya mempraktekkan gerakan sepak sila dalam permainan sepak takrawsesuai dengan ilustrasi dan bantuan LKS yang diberikan guru. Guru menunjuk satu orang peserta didik yang siap untuk mempraktekan di depan teman-temannya beberapa teknik dasar dalam permainan sepak takraw.

Perwakilan dari kelompok tersebut mempraktekan teknik dasarsepak takraw dan teman-teman yang lainnya dapat melihat dan menilai apakah gerakan temannya sudah benar atau belum. Teman yang lainnya bisa memberikan masukan jika gerakan yang dilakukan kurang tepat. Proses pembelajaran dilanjutkan dengan cara yang sama sehingga semua kelompok dan perwakilannya mendapat giliran untuk mempraktekan pemahaman yang telah mereka miliki mengenai teknik dasar sepak sila dalam permainan sepak takraw. Setelah semua kelompok mendapat giliran, selanjutnya guru melakukan penilaian terhadap kemampuan dan pemahaman mereka mengenai materi yang telah diajarkan. Disini peneliti akan memberikan penghargaan dari hasil kerja atau belajar baik secara individu maupun kelompok berupa tepuk tangan ataupun pujian.

Pada kelompok kontrol yang mendapat pembelajaran dengan model pembelajaran konvensional, proses pembelajaran berjalan dengan baik. Namun tidak banyak peserta didik yang aktif sehingga suasana kelas juga kurang aktif. Walaupun terdapat beberapa peserta didik yang aktif, namun beberapa peserta didik yang lain cenderung hanya duduk dan mendengarkan.

Dalam penerapannya model pembelajaran konvensional masih mengalami beberapa kendala. Adapun kendalanya adalah tidak semua peserta didik memiliki kepercayaan diri yang kuat masih ada peserta didik yang malu-malu tampil di depan temannya untuk mempraktekan teknik dasar sepak sila, namun karena dorongan dari teman satu kelompoknya hal tersebutdapat di atasi walaupun masih malu tapi peserta didik mau tampil di depan. Oleh karena itu diperlukan peranan guru untuk membimbing peserta didik supaya dapat ikut berperan aktif dalam proses pembelajaran sehingga mereka yang kurang aktif tidak tertinggal. Walaupun sebagian kecil kelompok masih tetap takut untuk mencoba, akan tetapi ada beberapa kelompok yang telah berani mencoba menujukan diri mereka

Berdasarkan hasil pengujian
hipotesis dan gambaran diskriptif
perbandingan masing-masing pembelajaran yang diterapkan, dapat dilihat bahwa model pembelajaran kooperatif tipe STAD lebih tinggi dari pada model pembelajaran koonvensional yang biasa diterapkan di kelas. Hal ini dibuktikan dengan hasil post-test yang menunjukkan bahwa hasil belajar PJOK peserta didik yang mengikutimodel pembelajaran kooperatif tipe STAD lebih tinggi dari pada peserta didik yang mengikuti model pembelajaran konvensional.

\section{PENUTUP \\ Simpulan}

Berdasarkan hasil analisis data dan pembahasan dapat disimpulkan bahwa penerapan model pembelajaran kooperatif tipe STAD berpengaruh signifikan $(p>0,05)$ terhadap peningkatan hasil belajar materi teknik dasar sepak sila dalm permainan sepak takrawpada siswa kelas IX A SMP Negeri 4 Kubutambahan tahun pelajaran 2019/2020. 


\section{Saran}

Berdasarkan hasil analis data dan pembahasan, maka dapat diajukan beberapa saran untuk proses pembelajaran dan penelitian lebih lanjut sebagai berikut. (1) Bagi guru PJOK, model pembelajaran kooperatif tipe STAD dapat dijadikan salah satu alternatif pembelajaran yang dapat diterapkan di kelas. (2) Penelitian ini dilaksanakan pada pokok bahasan teknik dasar teknik dasar sepak sila dalm permainan sepak takraw di kelas IX A SMP Negeri 4 Kubutambahan, sehingga untuk memperoleh bukti-bukti yang lebih umum dari penerapan model pembelajaran kooperatif tipe STAD diharapkan peneliti lain untuk mencoba pada pokok bahasan lain untuk mengetahui pengaruh penerapan model pembelajaran kooperatif tipe STAD dalam pembelajaran PJOK secara lebih mendalam.

Penelitian ini hanya mengukur ada atau tidaknya pengaruh dari model pembelajaran kooperatif tipe STAD terhadap hasil belajar teknik dasar teknik dasar sepak sila dalm permainan sepak takraw tanpa meneliti lebih jauh arah pengaruh yang diberikan. Di waktu mendatang dapat dilakukan suatu penelitian untuk meneliti sejauh mana arah pengaruh yang diberikan oleh model pembelajaran kooperatif tipe STAD terhadap hasil belajar PJOK peserta didik.

\section{DAFTAR PUSTAKA}

Arimbawa, I G A Adi, dkk.2017. "PengaruhPenerapan Model PembelajaranKooperatifTipe STAD Berbantuan Media Gambar Terhadap Hasil Belajar Teknik Dasar Passing Sepak Bola". Jurnal Pendidikan JasmaniOlahraga dan Kesehatan, Undiksha.https://ejournal.undiksha.a c.id/index.php/JJP/article/view/1134 0/7247(Diakses pada Rabu 6 November 2019).
Awan, I Ketut Ldy, dkk. 2017. "Pengaruh Model Pembelajaran Kooperatif Tipe STAD Terhadap Hasil Belajar Teknik Dasar Passing Control Sepak Bola". Jurnal Pendidikan Jasmani Olahraga dan Kesehatan, Undiksha.

Hamdu, Ghullam. 2011. Pengaruh Motivasi Belajar Siswa Terhadap Pestasi Belajar Ipa Di Sekolah Dasar. Jurnal Penelitian Pendidikan Vol. 12 No. 1, April 2011.

Majid, Abdul. 2009. Perencanaan pembelajaran. Bandung: PT Remaja Rosdakarya.

Paramitha, Sandey Tantra. 2018. Revitalisasi Pendidikan Jasmani untuk Anak Usia Dini melalui Penerapan Model Bermain Edukatif Berbasis Alam. Jurnal Pendidikan Jasmani dan Olahraga 3 (1) (2018).

Slavin, Robert E. 2010. Cooperative Learning. Teori, Riset, and Praktik. Bandung: Nusa Media.

Suarta I Komang, dkk. (2017). "Pengaruh Penerapan Model Pembelajaran Kooperatif Tipe Student Teams Achievement Division (STAD) Terhadap Hasil Belajar Teknik Dasar Passing Sepak Bola". Jurnal Pendidikan Jasmani olahraga dan kesehatan, Undiksha.

Sutrisno. 2016. Berbagai Pendekatan Dalam Pendidikan Nilai Dan Pendidikan Kewarganegaraan. Jurnal Dimensi Pendidikan dan Pembelajaran Vol.5 Januari 2016.

Tama, I Gede Surya, dkk. 2019. "Pengaruh Model Pembelajaran Kooperatif Tipe Student Teams Achievement Division (STAD) Terhadap Hasil Belajar Passing 
Jurnal Ilmu Keolahragaan Undiksha p-ISSN : 2613-9693 | e-ISSN : 2613-9685 Volume 8 Nomor 3 Tahun 2020

Sepakbola". Jurnal Penjakora, Volume 6 No 1, April 2019.
Trianto. 2007. Model-Model Pembelajaran Inovatif Berorientasi Konstruktivistik. Jakarta. Prestasi Pustaka. 